resins and plastics from waste products. He was the owner of a number of patents relating to textiles, wood. products, mineral waxes, etc. He was in touch with all the chief industrialists in India and had connexions with many leading technologists in other countries; furthermore, he was skilled in negotiation, so that, with his experience in university life and his many personal scientific friends, he became invaluable as the centre of the growing scientific organization within the Government of India. When national independence came, the schemes on which his heart was now set quickly took shape. Some of them, indeed, had already been decided (for example, the building of a National Physical Laboratory).

Bhatnagar took a leading part in starting a number of projects, such as the formation of Indian Rare Earths, Ltd., for the processing of monazite sands and the search for atomic minerals. A number of metallurgical and chemical processes were developed or changed to suit Indian conditions and India's needs; for example, the enrichment of manganese ores proved a valuable enterprise.

His administrative successes were frequent; it may be mentioned that he was successful in gaining exemption from tax for expenditure on research, and from customs duties on scientific instruments essential for research. He was active in promoting the regional technological institutions, the Standards Institution and the National Research Foundation, and was a very useful member of the Council of the Indian Institute of Science, Bangalore. $\mathrm{He}$ instituted a documentation centre which was accommodated in the National Physical Laboratory building.

Bhatnagar took a lead in all that was going on in science in India. Before the War he had been sectional president (chemistry) of the Indian Science Congress (1928 and 1938). He was general president in 1944-45. He was president of the National Institute of Science of India (1947 and 1948), and as president in his address at the thirty-sixth session of the Indian Science Congress, he appealed to the young scientists of India for zeal in the cause of science and its application and zest for research.

He attended many conferences in foreign lands, as representative of India. He was a delegate to the Empire Universities Congress at Edinburgh (1931) and at Cambridge (1936); to the British Association and the Michael Faraday centenary celebrations (1931), and at the Liverpool meeting so far back as 1923. $\mathrm{H}_{\Theta}$ was a member of the Indian Scientific Mission for the Government in 1945 and leader of the official delegation at the Empire Scientific Conference in 1946, and a member of the Indian Atomic Energy Commission which visited Great Britain in 1948. He attended the United Nations Scientific Conference on Utilization and Conservation of Natural Resources in New York, 1948. He made many tours to Europe and America in connexion with his work, and these included recently visits to the U.S.S.R. and to South America.

Bhatnagar was an honorary D.Sc., Oxford (1946), and had received the honorary doctorate of Delhi, Allahabad and Patna, and was honorary professor of chemistry of the Universities of Delhi, Benares and the Punjab. He was a Fellow of the Syndicate and member of Council of Benares University. He was a Fellow of University College, London. He was a Fellow of the Institute of Physics and of the Royal Institute of Chemistry (London), and was made an honorary member of the Society of Chemical Industry (London) in 1943 and honorary vice-president (1945-
48). He was a past-president of the Indian Chemical Society and recipient of the Reddy Prize in Chemistry, 1947.

The joy of Bhatnagar's full, eager life was marred by the loss of his wife, Srimati Iajwanti, in 1945. He had two sons and two daughters. A son and daughterin-law lived with him, and his home-life was still a happy one. He had a little farm outside Delhi in which he took great pleasure. But one could not imagine his tireless soul resting at ease in this world while there was work to be done. Providence ordeined that he should suddenly be taken away so that others, by the very shock of his loss, may be fired with his zeal. He has provided the means for scientists in India in many branches of science to do great work.

Alfred C. Egerton

\section{Dr. G. F. C. Searle, F.R.S.}

A memoriat service for the late Dr. G. F. C. Searle, a former Fellow of Peterhouse, Cambridge, who died on December 16, was held in the College Chapel on January 21, at which colleagues, former pupils and friends gathered as a tribute to the passing of a notable personality.

Searle was the son of the late Rev. W. G. Searle and was born in the vicarage at Oakington, Cambridgeshire, on December 3, 1864. His ninetieth birthday was celebrated by a tea-party at the Cavendish Laboratory on December 3 last, when a large and distinguished company heard him give an account of his boyhood and youth, and of his introduction to physics when taken by his father to see the newly erected Cavendish Laboratory and shown over the building by James Clerk Maxwell, then recently appointed the first Cavendish professor of experimental physics.

Searle won a foundation scholarship at Peterhouse and, entering the University, read for the Mathematical Tripos, which he took in 1887 , being classed as a Wrangler. In the following year he studied physics for Part II of the Natural Sciences Tripos. $\mathrm{He}$ began research work in 1888 in collaboration with Prof. J. J. Thomson on a determination of the ratio of the electromagnetic unit of electricity to the electrostatic unit, a research which was published in the Philosophical Transactions of the Royal Society. This was followed by many independent publications, mostly dealing with magnetic measurements or electromagnetic theory, but occasionally with properties of matter or heat. These researches gained for him the fellowship of the Royal Society in 1905 and the award of the Sc.D. degree by the University of Cambridge in 1912.

Searle was appointed to a University demonstratorship in 1890 and to a University lectureship in 1900. He retired from both posts in 1935. At the outbreak of the Second World War, however, he returned to work again and only gave up finally, and with reluctance, at the age of eighty-three, having then worked under three Cavendish professors. Sir J. J. Thomson has placed it on record in his book, "Recollections and Reflections", that "Searle has done more for the teaching of practical physics at Cambridge than anyone else". He taught a large class in practical physics at the Cavendish Laboratory - that for students working for Part I of the Natural Sciences Tripos-and for more than forty years nearly every Cambridge man taking physics was at some time his pupil. On the occasion of his ninetieth 
birthday party, Searle claimed with pride to have taught more Fellows of the Royal Society than any other teacher, and also that both the father and the mother of the present Cavendish professor had been his pupils.

As a University lecturer Searle gave regular courses of lectures for Part II of the Tripos in classical electricity and magnetism and in heat. $\mathrm{He}$ also, for a time, gave lectures on mathematics for students of physics. But it was his work as a demonstrator which gave him his pre-eminence. He showed great skill in devising laboratory experiments suitable for instructing students, and in designing the necessary apparatus. It is these skills which have carried his name and his teaching methods into the physics departments of almost every university and technical college in the world, and into the science laboratories of most progressive schools. His experiments were never commonplace; their originality and elegance made a special appeal to students, so that they became keen to try them. With each experiment he supplied a manuscript, written in his own hand, giving an account of the underlying theory, followed by $a$ very full and clear description of the way the experiment should be made. Some of these manuscripts have been published by the Cambridge
University Press in a series of volumes. Displayed on the notice-board of his laboratory was a list of instructions and exhortations to students beginning work in practical physics. To many, the last paragraph of these was the most interesting. It dealt with the relations between students and their hardworked demonstrators, exhorting students not to become annoyed if they did not get all the attention to which they felt entitled, but to be patient and remember that "demonstrators are only human and need your sympathy and your prayers at least as much as other men".

Dr. Searle married, in 1904, the widow of Mr. Thomas Parsons, of Wimbledon, and would speak most feelingly of the great help and constant encouragement he had received from her throughout their happy married life. He was above all a staunch Christian. He was active as a lay reader of the Church of England and keen and enthusiastic about any duties he undertook. As a teacher his manner was perhaps rather brusque and a little forbidding to students meeting him for the first time; but his obvious earnestness and lively interest in them and their work soon overcame this, and he was held in respect and admiration by a large circle of students and friends.
Frank Horton

\section{NEWS and VIEWS}

\section{Rothamsted Experimental Station:}

Dr. R. K. Schofield

THE appointment of Dr. R. K. Schofield to be head of the Chemistry Department of Rothamsted Experimental Station, in succession to the late Dr. E. M. Crowther, is a tribute to his versatility. $\mathrm{He}$ went to Oundle School and won an entrance scholarship to Trinity College, Cambridge, in science and mathematics. $\mathrm{He}$ took physics, chemistry and botany in Part I of the Natural Sciences Tripos, and his progress was marked by the winning of $a$ senior scholarship and a first class in Part II (Physics). His special interest in the borderland between physics and chemistry led him to do his Ph.D. research on the physical chemistry of surfaces under Sir Eric Rideal. For two years he was lecturer in physics at Durham and then joined the Physies Department at Rothamsted, of which he became the head in 1947 in succession to Sir Bernard Keen. He is a recognized authority in the moisture relationships and colloidal aspects of soil, and in recent years has been particularly active in applying and extending the concept of the diffuse electric double layer. $\mathrm{He}$ has been chairman of the Colour Group of the Physical Society and was visiting professor of soil physics at Cornell University during the winter of 1951-52.

\section{Dr. H. L. Penman}

Dr. SCHOFLeld is succeeded as head of the Physics Department at Rothamsted by Dr. H. L. Penman, who graduated in the Newcastle Division of the University of Durham in 1930 with a first in physics. After research in acoustics with Dr. E. G. Richardson, he joined the Photochemistry Section of the British Cotton Industry Research Association in Didsbury, leaving in 1937 to go to Rothamsted. Until 1941 he worked on diffusion of gases and vapours in soil, soil temperature, and on drainage and evaporation. During 1941-44 Dr. Penman was in the acoustics section of the Mine Design Department, Admiralty, at Portsmouth. In 1944 he returned to Rothamsted to resume his evaporation studies, and since then has been able to show that the use of water by vegetation is a physical process the rate of which is dictated by weather, and is calculable from weather data. The general utility of this work in irrigation control and in hydrology led to an invitation from the Waite Agricultural Research Institute, Adelaide, to spend six months in Australia (1951-52), where, supported by a Nuffield Fellowship, Dr. Penman was able to study the water conservation and irrigation problems of south-east Australia. Dr. Penman has been honorary secretary of the London Branch of the Institute of Physies, has served on the board of the Institute, and at present is an honorary secretary of the Royal Meteorological Society and a vice-president of the Association Internationale d'Hydrologie Scientifique.

\section{Zoology at Fordham University :}

Prof. A. A. Wolsky

Prof. A. A. Wolsky, former professor of zoology in the University of Budapest and director of the Hungarian Biological Research Institute at Tihany, has been appointed professor of experimental embryology in Fordham University, New York. Following his formal education in Budapest, Dr. Wolsky did postgraduate work abroad under fellowships from the Hungarian Government, the Rockefeller Foundation and the Swedish Institute of Cultural Exchange. This included studies in London in 1931, Cambridge in 1934, and at the Wenner Gren Institute, Stockholm, in 1935. In 1947 the Hungarian Government permitted him to return to Stockholm for a year. At the end of that period he refused to return to Hungary. He joined Unesco as principal scientific officer for South-East Asia, stationed at Djakarta, Indonesia. $\mathrm{H}_{\Theta}$ has held that position for six years. Dr. Wolsky is the author of 